\title{
Ou wyn in nuwe sakke: werk die ou etiek vir die nuwe geneeskunde?'
}

\author{
Anton A. van Niekerk \\ Sentrum vir Toegepaste Etiek \\ Universiteit van Stellenbosch \\ STELLENBOSCH
}

\begin{abstract}
Old wine in new skins: Does the old ethics work for the new medicine?

This article investigates and analyses the shifts that have taken place in the discourse about morality and ethics as they have developed in the history of Western medicine. The author argues that many of the forms of moral reasoning aligned to certain practices of medical care in the past have become inappropriate and obsolete for the challenges of a new, posimodern situation in medical care. He specifically investigates the consciousness of limits which is characteristic of the contemporary discourse on medical ethics, and in this regard analyses three manifestations of these limits, viz. the limits of competence, of compassion and of the rights of physicians.
\end{abstract}

\section{Inleiding}

Die tema wat in hierdie artikel aan die orde gestel word, is enkele van die merkwaardige verskuiwings wat die diskoers rondom moraliteit en etiek in die geskiedenis van Westerse geneeskunde ondergaan het. Hierdie verskuiwings vorm uiteraard ' $n$ onderdeel van 'n breër kultuurhistoriese verhaal wat nie in hierdie artikel bespreek word nie. Ek gaan slegs wys op enkele tendense in die geskiedenis van die praktyk van geneeskunde, en op die implikasies daarvan vir morele besinning. Ek doen dit in die oortuiging dat die geskiedenis van morele nadenke ten opsigte van gesondheidsorg sal aantoon hoe indringend die konteks waarin morele besinning ten opsigte van medies-etiese probleme moet plaasvind, verander het. Ek is daarvan oortuig dat sekere antieke, dog meermale nagelate vorme van morele diskoers die potensiaal het om die meeste kontemporêre

I Finansiêle ondersteuning deur dic Sentrum vir Wetenskapsontwikkeling van die RGN vir die navorsing vervat in hierdic artikel, word hiermee erken. Standpunte wat ingeneem word, en gevolgtrckkings wat bereik word, is dic van dic outcur en kan nic aan dic SWO tocgeskryf word nic.

Ek bedank graag die dric anonieme Koers-keurders vir waardevolle kommentaar ter verbetering van die oorspronklike manuskrip 
Ou wyn in mrue sakke: werk die ou etiek vir die mmie geneeskunde?

probleme in hierdie veld met meer wysheid te hanteer as wat moontlik gemaak word deur die modernistiese obsessie met beginsels, wette en strak omlynde teorieë wat op 'n meganiese manier in die mediese praktyk vaardig gemaak probeer word

Kortom, in dié artikel wil ek die wysheid uitwys van 'n insig wat voortvloei uit 'n aanpassing van Jesus se waarskuwing om nie "nuwe wyn in ou sakke te gooi" nie (Matt. 9:17). Eerder as om 'n saak daarvoor te probeer uitmaak dat 'n nuwe situasie in die geneeskunde die ontwikkeling van 'n radikaal nuwe etiek vereis, glo ek dat gevestigde en bewese vorme van morele diskoers hul belang tot in ons tyd behou, mits hierdie "ou etiek" op 'n relevante wyse vir 'n nuwe situasie geïnterpreteer en aldus toegepas word. Die beste etiek, soos die beste rooiwyn, bly die ou etiek. Maar hierdie "ou etiek", soos ou wyn, kan in "nuwe sakke" gegooi word. Soos dit insgelyks vir die kerk nodig is om die bevryding van sy "ou, ou tyding" vir die mens van die hede bevatlik te maak in 'n diskoers wat dié mens betrek, so is dit myns insiens vir die mediese etiek moontlik om antieke bronne van morele diskoers te herontgin met die oog op ' $n$ fundamenteel veranderde situasie in die kontemporêre geneeskundige praktyk. Terwyl ons daarom kan ag slaan op die Bybelse waarskuwing om nie nuwe wyn in ou sakke te gooi nie, meen ek dat ou (en daarom goeie - selfs die beste!) wyn wel in nuwe sakke gegooi kan word.

'n Laaste voorwoord: die leser sal spoedig bewus word van die feit dat die voorbeelde waarvan ek gebruik maak, grootliks ontleen is aan die die geskiedenis van persone en gebeure in die mediese praktyk in Brittanje en die VSA. Ek kon tot op hede nog nie bevredigende toegang tot bronne verkry wat die situasie in die geskiedenis van hierdie land genoegsaam toelig nie. Daar moet nog 'n behoorlike geskiedenis van mediese etiek in SA geskryf word. Ek leun vir my voorbeelde taamlik swaar op die boeiende onlangse boek van Albert Jonsen - 'n boek waaraan ek die tweede deel van die artikel se titel ook ontleen: The New Medicine and the Old Ethics (Jonsen, 1990).

Ek wil begin met die interpretasie van 'n algemene historiese waarneming wat Jonsen maak (vgl. sy 1990:4-13). Sedert die heel vroegste tye was daar nog altyd sprake van 'n spanning tussen selfbelang en altrulisme in die morele verantwoording van die geneeskundige praktyk. In die vroegste Hippokratiese tradisie van geneeskunde by die Grieke staan selfbelang naamlik nog voorop vir dokters. Dit sal ons loon om te onthou dat geneeskunde in die tyd van Hippokrates nog grootliks beskou was as 'n kunsvorm. Die oermotief vir die beoefening daarvan was: doen wat jy doen goed, sodat jy (as dokter) ' $n$ goeie reputasie kan verwerf. Die belange van die praktiserende geneesheer, en veral sy vermoë om 'n stewige en stabiele kliëntebasis op te bou, staan voorop as motief vir die werk wat hy doen. Dit mag tans wel vreemd klink, maar die navolging 
Anton A. van Niekerk

van selfbelang hoef natuurlik nie inherent immoreel te wees nie, mits dit deurentyd begelei word deur ' $n$ tweede beginsel wat ook in die Hippokratiese tradisie gefigureer het, en wat vereis: "doen ten minste geen kwaad aan 'n ander nie" (vgl. hieroor ook Harris, 1985:28-47 se indringende bespreking).

Altruïsme as motief vir mediese sorg verskyn eers (op die vroegste) op die toneel in die tweede eeu na Christus, toe die Stoïsynse en Christelike tradisies van geneeskunde begin konvergeer het. Die Christelike kerk self was aanvanklik taamlik wantrouig teenoor die moontlikhede en praktyk van geneeskunde, maar aanvaar siekesorg gaandeweg as 'n plig wat die liefde aan ons oplê. Die invloed van Jesus se gelykenis van die barmhartige Samaritaan (vgl. hieroor veral Jonsen, 1990:38-60) begin deurslaggewend word: dit impliseer die plig om siekes se wonde te verbind deur menslike instrumente, en om om te sien na verdere sorg (in die herberg) op onkoste van die versorger. Monnike en nome word gaandeweg self geneeshere; die plig om na siekes en noodlydendes om te sien, word met verloop van tyd gevoeg by hul plig tot selfopoffering en askese. Nou word die sentrale motief vir gesondheidsorg die vermaning van Jesus in Matteus 25:36, 40: "Toe ek siek was, het julle my kom besoek ... Vir soverre julle dit gedoen het aan een van die geringstes van hierdie broers van my, het julle dit aan my gedoen". So is die tweede motief vir mediese sorg - altrulisme - gaandeweg in die tradisie ingevoer.

Dat daar van meet af 'n spanning tussen selfbelang en altruisme bestaan het, blyk onder andere uit die instelling van "lisensies" vir mediese sorg aan geneeshere gedurende die Middeleeue. Lisensies spruit voort uit die erkenning dat geneeskunde ' $n$ vaardigheid is wat so raar is dat dit (soms teen 'n hoë prys) verkoop kan word. Hierdie praktyk dui enersyds daarop dat die professie waak oor die belange van diegene wat die lisensie het, ten einde slegs die lisensiehouers in staat te stel om die voordele van die besit daarvan (geld, status, dank) te bekom. (Hier gaan dit duidelik om selfbelang.) Andersyds reik die samelewing die lisensie uit omdat dit goeie sorg van die lisensiehouers verwag. Die houer van die lisensie kan nie waag om swak of geen sorg te verleen nie. Vanweë lisensièring word verhale van pasiënte wat weggewys word van spreekkamers omdat hulle nie kan betaal nie, van die vroegste tye af met morele verontwaardiging bejeën. Wanneer van mediese rantsoenering gepraat word, reageer die meeste lede van die samelewing deurgaans met ongeloof en verbystering. Bewaar ook die dokter wat sorg aan sy pasiënt nalaat ter wille van sy tennisafspraak of 'n sosiale verpligting! Hier gaan dit duidelik weer om altruisme: die moderne geneesheer is die erfgenaam van die monastiese tradisie: hy of sy is die dienaar van "our lords, the sick" (Jonsen, 1990:10).

Die punt is dat die praktyk van lisensiëring (of in sy moderne, Suid-Afrikaanse gestalte: "Registrasie by die Mediese en Tandheelkundige Raad") die paradoks 
Ou wyn in miwe sakke: werk die ou etiek vir die nuwe geneeskunde?

van die spanning tussen selfbelang en altruisme versterk. Vergelyk byvoorbeeld hoe hierdie twee motiewe teen mekaar afgespeel word in die kompetisie om toegang tot mediese skole te verkry (met die gepaardgaande belofte van 'n hoë lewenstandaard wat daardeur belowe word), enersyds, en die asketisme wat die lewe van 'n huisdokter of kliniese assistent kenmerk (lang ure, min slaap, volgehoue blootstelling aan ongure pasiënte, ensovoorts). Vergelyk ook die herinnering aan altruisme by elke seremoniële geleentheid waar dokters bymekaar is, byvoorbeeld tydens die aflegging van die Eed van Hippokrates. Die instandhouding van die paradoks tussen altruisme en selfbelang word skynbaar ook intakt gehou deur en aangemoedig in die proses van mediese opvoeding. In die betoog wat hier volg, sal dit meermale blyk hoe die spanning tussen selfbelang en altruisme figureer in die tradisie van medies-etiese besinning, en hoe dit hierdie besinning toelig.

Ons let vervolgens op enkele sentrale temas wat die uniekheid van die omstandighede waarin mediese etiek vandag bedryf word, ten aansien van die eise van tradisionele etiese besinning, toelig. Oor die algemeen kan gesê word dat hedendaagse morele besinning oor geneeskundige praktyke gekenmerk word deur 'n steeds groeiende bewussyn van grense en beperktheid. Dit staan in 'n sekere sin haaks op die groei van die werklike mag en bevoegdheid van mediese praktisyns vanweë die tegnologiese rewolusie, en die wyse waarop laasgenoemde, saam met ander sosiologiese tendense wat hieronder aangetoon sal word, dokters se mag, status en invloed uitgebrei het. Om dit in kontemporêre filosofiese jargon te formuleer: terwyl die praktyk van die geneeskunde in 'n modernistiese rat gegaan het (groter mag, groter uniformiteit, groter konsensus, gebaseer op die akkoord van professionele kodes en lisensiëring), blyk dit dat die morele besinning oor wat ons van dit alles moet dink, 'n groeiende postmodernistiese sensitiwiteit ondergaan: 'n bevraagtekening van die waarde van ongebreidelde kompetensie, gefokus op slegs die een pasiënt waarmee die dokter hier en nou te make het; 'n besef van die feitlik onhanteerbare en onbekostigbare aansprake van die moderne geneeskunde op samelewingsbronne; 'n skepsis oor die wysheid van ongehumaniseerde tegnologiese innovasie; en 'n nuwe aandrang deur pasiënte op beskikkingsreg oor hul eie liggame, medeverantwoordelikheid vir hul behandeling en gelykheid in die bepaling van die aard van en voorwaardes vir dokter-pasiënt-verhoudings. Met inagneming van die feit dat volledigheid hier nie nagestreef word nie, volstaan ek met die bespreking van drie sodanige instansies van 'n opkomende grensbewussyn: die grense van kompetensie, van medelye en van dokters se regte.

\section{Die grense en fokus van bevoegdheid}

Die eerste tema is die probleem insake die grense en fokus van bevoegdheid (vgl. hieroor veral Jonsen, 1990:17-37). Hierdie probleem het die eerste keer die 
Anton A. van Niekerk

aandag van openbare belangstelling getrek na aanleiding van dr. Belding Scribner se deurbraak met die eerste suksesvolle tegniek vir volgehoue nierdialise op Clyde Shields in 1960.2 In 'n belangrike sin was die eerste oorplanting van 'n mensehart deur Chris Barnard in Desember 1968 ook 'n paradigma-instansie van hierdie nuwe biomediese problematiek. Soos nooit tevore nie, het hierdie twee gebeure die omvang en reikwydte van medici se magte en bevoegdhede beklemtoon - magte en bevoegdhede wat radikaal uitgebrei is as gevolg van die moontlikhede wat deur nuwere tegnologie geskep is. Die vermoede wat lank reeds bestaan het dat medici onderweg is na 'n situasie waarin hulle beskikkingsmag verwerf het, nie slegs oor siekte nie, maar oor lewe en dood self, is aanmerklik versterk. Dit het ons opnuut met die vraag begin konfronteer of ons die konsekwensies van hierdie uitgebreide mag kan peil en verstaan, of 'n ongebreidelde uitbreiding van hierdie magte altyd en noodwendig ' $n$ goeie ding is, en of daar grense aan dokters se bevoegdheid gestel kan en moet word

As ons die etiese dimensie van bogenoemde probleem in sig wil kry, sal dit ons loon om in die eerste plek daarop te let dat daar, veral sedert die laat negentiende eeu en tot baie onlangs in die wêreld van die institusionele geneeskunde, weinig of geen morele spanning aangevoel is tussen kompetensie en die behorenseis van die etiek nie. Inteendeel: kompetensie is merendeels aangebied as die belangrikste antwoord van die geneeskunde op die behorenseis. Ons sou na hierdie verskynsel kon verwys as die voorkoms en houvas van 'n kompetensie-etiek in die institusionele geneeskunde oor 'n lang tyd. Hiervolgens vereis effektiewe geneeskunde op die etiese vlak 'n optimale bemeestering van die wetenskap en van die vaardighede van diagnose en terapie, tesame met ' $n$ waardering van die persoonlike en sosiale aspekte van 'n pasiënt se gesondheid en siekte.

Die klem op kompetensie as motief vir mediese sorg is op sigself niks nuuts nie; trouens, dit verteenwoordig een van die oudste motiewe in die geneeskunde en kan teruggevoer word na Hippokrates. Wat nuut is, is die dimensies en afmetings wat kompetensie begin aanneem het vanweë die tegnologiese rewolusie van ons tyd, en die eiesoortige etiese probleme wat daardeur opgeroep is.

Ek wil in dié verband in aansluiting by Jonsen (1990:26-31) en ter illustrasie verwys na die wyse waarop hierdie kompetensie-etiek vervolmaak is in die

2 Die tegnick vir nierdialise is weliswaar reods gedurende die veertigerjare deur dr. Willem Kolff ontwerp, maar dit kon slegs aangewend word vir tydelike verligting vir pasiente met kritieke nicrversaking; pasiente met onomkeerbare en totale nierversaking het stceds bly sterf. Die "Scribner Shunt" wat die eerste keer suksesvol op Shields toegepas is, was 'n nuwe tegnick waardeur dic pasient se hele bloedsomloop met 'n buis aan dic dialiscmasjien gekoppel is, gesuiwer is en van tyd tot tyd, soos nodig, herhaal kon word. Daarmee is die moontlikheid geskep om pasiente met enstige nierversaking onbepaald aan die lewe te hou, soos Shiclds vir die volgende 12 jaar (vgl. vir hierdie verhaal Fox \& Swazy, 1974). 
Ou wyn in miwe sakke: werk die ou efiek vir die mowe geneeskunde?

beskouinge van dr. Richard Cabot (1868-1939), een van die mees invloedryke professore aan die Harvard Medical School in sy tyd. Kompetensie is naamlik deur Cabot primêr verstaan as kliniese kompetensie. Die sleutel tot die optimale, deugdelike versorging van die pasiënt lê in die bemeestering van die eksperimentele wetenskap, uitgebreide metodes van kliniese evaluering en bewese patrone van kliniese sorg. 'n Verdieping van die etiese dimensie van geneeskunde verg in terme van hierdie model niks meer nie as 'n verdieping van wetenskaplike kennis en die bemeestering van steeds nuwe tegnieke van sorg. Die etiese eis aan en plig van die gesondheidswerker is om alle moontlike kennis en vaardighede tot beskikking van elke pasiënt wat moontlik daardeur bevoordeel sou kon word, te stel.

Een van die opvallendste kenmerke van die situasie waarin geneeskunde vandag beoefen word, is die wyse waarop bogenoemde ethics of competence uitgedaag word. Kompetensie-etiek is 'n grootliks uitgediende etiek, so uitgedien soos die terapeutiese tegnieke wat gangbaar was in die tyd van dr. Cabot. Die rede waarom dit uitgedien is, is dat dit as etiek nooit genoegsame aandag geskenk het aan die vraag na die grense van kompetensie nie. Kompetensie is sonder twyfel 'n deug. Die begrip "deug" vir Aristoteles beteken 'n middeweg tussen twee uiterstes ${ }^{3}$. Kompetensie as deug kan bygevolg tekortskiet, sowel wanneer daar te min daarvan is, as wanneer daar te veel daarvan is. Dit is begryplik dat inkompetensie die ondeug is waarteen Cabot in die laat negentiende en vroeg twintigste eeu veral wou veg. Vandag het die pendulum radikaal geswaai. Van die vernaamste etiese dilemmas waarin kontemporêre geneeskunde sigself bevind, het nie te make met 'n gebrek aan kompetensie nie, maar met 'n oormaat van kompetensie. Dit is die gevolg van die geweldige mag wat die tegnologie hedendaags in die hande van medici kom plaas het. Dit bring ongekende kompetensie tot stand, sonder oplossings vir probleme soos byvoorbeeld of volgehoue tegnologiese ingrepe altyd geregverdig is, en of alle mense ewe veel van 'n aanspraak het op die beperkte voorsiening wat beskikbare bronne vir nuwe tegnologieë kan tref.

Daarom is die vraag na die grense van kompetensie een van die dringendste etiese vrae op die hedendaagse geneeskundige toneel. Niks illustreer dit beter nie as die verskynsel van intensiewe sorg, en die spesiale "eenhede vir intensiewe sorg" wat, meesal teen astronomiese koste, toegerus met die beste en die

3 "... courage lies between rashness and timidity, justice between doing injustice and suffering injustice, liberality between prodigality and meanness. For each virtue therefore there are two corresponding vices ... Hence judgement has an indispensable role in the life of the virtuous man which it does not and could not have in, for example, the life of the merely law-abiding or rule abiding man" (MacIntyre, 1981:144. Vir sy pakkende bespreking van dic Aristoteliaansc dcugdclcer, kyk sy 1981 : 137-53). 
effektiefste wat tegnologies beskikbaar is, in moderne hospitale ingerig word. Hier is dit moontlik om sterwende mense amper onbepaald aan die lewe te hou; hier kan premature babas intensief geventileer word totdat hulle longe hopelik in 'n stadium onafhanklik begin funksioneer. Babas wat so vroeg soos op 24 weke gebore word, word hedendaags in die VSA amper roetinegwys deurgehaal, maar wel teen 'n koste van ongeveer $\$ 100000$ of R440 000 per kind! Hier word moontlik wat vroeër amper ondenkbaar was - met die beste tegnologie, onder intensiewe toesig ('n volledig opgeleide suster per pasiënt) - maar geweldig duur. En die aansprake op hierdie soort sorg neem daagliks toe in intensiteit. Dis duidelik dat die aanvraag die voorsiening hier totaal oorskry - en dit vra van die moeilikste beslissings wat eties denkbaar is. Wie mag lewe, en wie moet sterwe, en hoekom? In ons nuwe situasie, behandel dokters nie te sleg nie, maar te goed!

Ek wil my bespreking van hierdie kwessie afsluit deur op twee verdere aspekte te wys. Die eerste is ' $n$ insig van Jonsen, en die tweede ' $n$ punt wat ek meen addisioneel gestel moet word.

Jonsen (1990:31 e.v.) stel naamlik in sy bespreking van hierdie vraagstuk, eerstens die vraag of geneeskunde in die toekoms nie al hoe minder op die individuele pasiënt, en al hoe meer op populasies toegespits behoort te word nie Die moontlikheid word veral geskep namate die genetiese basis van talle siektes aan die lig kom, byvoorbeeld sekere kankers, skisofrenie, Huntington se Siekte, suikersiekte, artritis, ensovoorts. Die vraag is of in situasies waar die individuele pasiënt primêr gesien word as ' $n$ lid van 'n populasie met 'n geneigdheid tot 'n sekere siekte, genetiese ingrepe nie in die toekoms toenemend gebruik sal word om voorkomend op te tree nie. Indien siekte in wese geneties gebaseer is - en in watter mate laasgenoemde waar is, sal waarskynlik aan die lig tree in die sogenaamde "Genome Project" - is die potensiële slagoffers nie bloot individue nie, maar totale populasies

Selfs in intensiewesorg-geneeskunde is daar ' $n$ groeiende belangstelling in die vasstelling van kenmerke van pasiënte in die lig waarvan uitgemaak kan word of hulle statisties 'n beter kans het om by intensiewe sorg te baat. 'n Groeiende aantal studies probeer die waarskynlikhede spesifiseer dat 'n sekere mediese ingreep 'n sekere resultaat sal hê, of, omgekeerd, wat die voorwaardes is waaronder die waarskynlikheid vir sukses laag is. Een van hierdie sisteme het die opvallende naam APACHE (Acute Physiology and Chronic Health Evaluation). Die etiese vraag wat hierdie studies ontlok, is of 'n statistiese uitdrukking van waarskynlikheid moet kan dien as ' $n$ intrinsieke grens van kompetente mediese optrede.

Al bogenoemde oorwegings is aanduidings daarvan dat die individuele pasiènt nie meer die uitsluitlike fokuspunt van die moderne geneeskunde is nie, omdat 
Ou wyn in move sakke: werk die ou etiek vir die mwe geneeskunde?

geneeshere vandag in staat is om in te gryp op "populasies" van pasiënte. Die pasiënt word toenemend gesien as 'n verteenwoordiger van 'n bepaalde populasie.

Die belangrikste implikasie hiervan vir ons huidige doel is dat hierdie verskuiwing vanaf 'n pasiënt-gesentreerde geneeskunde na 'n populasiegesentreerde een ' $n$ beslissende uitdaging stel aan mediese etiek - veral aan daardie mediese etiek wat gedrenk is in die imperatief van kompetensie in pasiëntesorg. Die vraag is inderdaad of die etiek van kompetensie mediese aandag vra vir individue bo en behalwe die pasiënt wat in ' $n$ bepaalde stadium voor die geneesheer verskyn. Die punt is dat ons hier te make het met aspekte van die postmoderne wêreld waarvoor bestaande etiese teorieë en kodes beswaarlik genoegsame voorsiening maak. Tradisionele medies-etiese besinning was grootliks afgestem op die verhouding tussen dokter en individuele pasiënt. Soos Jonsen (1990:35) dit stel: "... the ethical problems posed by the new medicine reflect the omnipresence of the population that stands behind the relationship". Daar is met ander woorde nie slegs grense aan bevoegdheid nie. Daar is ook nuwe en radikale vrae insake die verantwoorde fokus van bevoegdheid.

Ter aanvulling van hierdie insigte van Jonsen verwys ek ook na die insigte van Hans Jonas insake 'n nuwe dimensie wat moraliteit in 'n postmoderne konteks verkry, naamlik verantwoordelikheid teenoor mense wat in tyd en ruimte ver van ons geskei is.4 Jonas het die meeste van sy werk bestee aan die teenstelling tussen wat moraliteit moet en kan doen wanneer modernisasie op 'n ongebreidelde wyse veld wen. Wat hy veral in dié verband in ag neem, is die verskynsel van moderne tegnologie.

In laasgenoemde verband wys hy daarop dat agente wat moreel verantwoordbaar is, deesdae kwalik vir hulself bevredigende voorstellings kan maak van al die moontlike gevolge van hul dade. Ons moet verstaan dat, wat ook al die (moontlik ook morele) motiewe van waaruit ons hedendaags handel, ons dade mense wat in ' $n$ ander tyd of omgewing as onsself lewe, bewustelik of onbewustelik kan affekteer. In voor-modeme samelewings was moraliteit volgens Jonas 'n "morality of proximity". Hierdie moraliteit is uitgedien in 'n samelewing waarin wat ons doen 'n effek het op mense oor 'n groot afstand. Jonas sê byvoorbeeld:

The good and evil about which action had to care [traditionally - in premodern times] lay close to the act, either in the praxis itself or in its

4 Ek het aanvanklik met Jonas se werk kennis gemaak via die besprekings daarvan in Zygmunt Bauman se bock Postmodern Ethics (Bauman, 1993). Vir dic kort besprcking hicrbo verlaat ck my grootliks op Bauman (1993:217-222). 
Anton A. van Niekerk

immediate reach, and were not a matter of remote planning. The proximity of ends pertained to time as well as space ... The ethical universe is composed of contemporaries and neighbours ... All this has decisively changed. Modern technology has introduced actions of such novel scale, objects, and consequences that the framework of former ethics can no longer contain them (Jonas, 1974:7, 8, soos aangehaal deur Bauman, 1993: 217-218)

Hierdie uitspraak ondersteun Jonsen se standpunt dat die ongekende kompetensie wat moderne tegnologie op mediese gebied moontlik maak, 'n reikwydte en effek het wat verder strek as die individu wat hier en nou die geneesheer se aandag vra. Moderne geneeskunde moet leer saamleef met die etiese eis dat nie alles wat kan, ook gedoen behoort te word nie.

Die tweede punt waarop ek wil wys, is dat die ontwikkelinge waarna hierbo verwys is, op die etiese vlak die noodsaaklikheid daarvan beklemtoon dat wetenskaplike en tegnologiese vernuwing van meet af en deurgaans begelei behoort te word deur etiese doelwitformulering en besinning. Mediese kompetensie is uiteraard nie iets waarteen op etiese gronde in beginsel beswaar gemaak kan word nie; ons almal trek die voordeel daarvan dat dokters hedendaags soveel meer bevoeg is as byvoorbeeld 'n honderd of tweehonderd jaar gelede. Werklike mediese kompetensie moet egter onderskei word van blote tegniese vernuf. Kompetensie is iets anders as vernuf. Vernuf dui bloot op die vermoë om 'n klomp dinge te kan doen, sonder dat daar indringend besin is oor waarom ' $n$ mens dit doen en wat daarmee bereik word. Tegniese vernuf spruit voort uit die najaag van al die middele en metodes wat die tegnologie aan ons beskikbaar stel, bloot omdat dit nou moontlik word om nuwe dinge te doen. Kompetensie dui egter op iets meer. Dit dui op die aanwending van vaardighede - ook diè vaardighede wat voortspruit uit wetenskap en tegnologie - op so 'n wyse dat dit aangewend word ter ondersteuning van 'n heilsame menslike lewe. 'n Heilsame menslike lewe is 'n lewe met kwaliteit, 'n lewe wat meer behels as die blote uitvoering van meganiese biologiese funksies soos voedselinname en -uitskeiding. Vernuf wat niks anders op die oog het nie as die blote verlenging van menslike lewe ter wille van die voortsetting van biologiese funksies, is kwalik eties verantwoord. Die kompetente mediese dokter is die een wat tegnologie ondergeskik stel aan die eise van 'n heilsame en sinvolle bestaan. 'n Integrale deel van sodanige kompetensie is ' $n$ bewussyn van die grense van eie moontlikhede en bevoegdhede; 'n erkenning daarvan dat 'n punt êrens bereik kan word waar die magtige moderne mens die einde van die moontlikhede van sy eie magsuitoefening bereik het

Hierdie insigte het verreikende implikasies. Een, waarop ek graag wil wys, is dat dit my oortuiging oor 'n lang tyd bevestig dat geneeskunde net soveel 'n sosiale as 'n natuurwetenskap is. Dat geneeskunde 'n sosiale én 'n natuurwetenskap is, 
Ou wyn in mwe sakke: werk die on etiek vir die mwe geneeskunde?

is natuurlik reeds 150 jaar gelede deur die Duitse patoloog Rudolf Virchow voorspel (vgl. Virchow, 1879, vol. I.34. Vergelyk ook Jonsen se boeiende appèl vir erkenning van hierdie insig in sy 1990:141-160). Die rede daarvoor is nie alleen dat mediese aktiwiteite binne die grense en moontlikhede van die samelewing voltrek word nie. Die rede is ook en veral dat die werklike basis van biomediese kennis getuig van die sosiale en etiese dimensies daarvan.

\section{Die grense van medelye}

Onder hierdie opskrif gaan dit oor die etiese problematiek insake die regverdige toedeling van skaars mediese hulpbronne - 'n probleem wat in 'n belangrike mate die paradigma-instansie van die hedendaagse problematiek van die mediese etiek geword het. ${ }^{5}$ Hierdie probleem is natuurlik op sigself ook reeds gesuggereer deur die voorbeeld waarmee my bespreking in die vorige paragraaf 'n aanvang geneem het. Die dringende - en durende - probleem wat naamlik óók deur die geval van Clyde Shields en die "Scribner Shunt" op die agenda van medies-etiese besinning geplaas is, is: hoe besluit ons wie mag toegang tot hierdie behandeling hê? Hierdie vraag is aktueel, veral in die lig van die feit dat toegang tot dialisemasjiene beperk is vanweë koste-oorwegings. Dis 'n probleem wat onveranderd tot in ons tyd bestaan, en een na aanleiding waarvan daar daagliks in hospitale oor die hele wêreld besluite geneem word wat meebring dat bevoordeeldes die vooruitsig van verlengde en ongeveer normale lewens het, terwyl die benadeeldes bestem word om vinnig te sterf. (Vir 'n bespreking van die probleme van die sg. "God-committee" in Seattle wat moes besluit oor wie toegang het tot dialise, en die proses wat uitgeloop het op die deurvoering van federale wetgewing wat fondse bewillig het vir pasiënte met eindstadium-nierversaking, vgl. Jonsen, 1990: 46-47.)

Ek het reeds vroeër verwys na die wyse waarop altruilsme via die segetog van die Christendom in die vroeë Middeleeue 'n tweede, deurslaggewende motief vir mediese sorg naas selfbelang geword het. Die altruisme wat hierdeur posgevat het, het merendeels die vorm aangeneem van medelye (compassion), en wat onder laasgenoemde verstaan is, is grootliks geïnspireer deur die grondmetafoor van medelye wat verskaf is deur Jesus se gelykenis van die barmhartige Samaritaan. Medelye kompeteer dus sedert die vroegste tye met selfbelang en kompetensie as motiewe vir geneeskundige sorg. Die ideale geneesheer is nog altyd gesien as die persoon wat blyke gee van sowel die deug van kompetensie as

Jonsen se bespreking van hierdie problematiek, waarby ek grootliks aansluit, is veral op p. 38 60 van sy bock (1990), maar duik in ander kontekste ook gerceld op. Vir 'n indringende en belangwekkende bespreking van die wyse waarop die bronnetekort, oftewel "medicine's ncw economics", 'n radikale herbesınning oor dic aard en voorwaardes vir mediese ctick in die VSA noodsaak, vergelyk Morreim (1995). 
dié van medelye. 'n Tekort aan enigeen van dié twee by die geneesheer is nog altyd beskou as ' $n$ belangrike rede vir morele blaam.

Die bitterste feit van geneeskundige sorg vandag oor die hele wêreld is dat medelye en kompetensie eenvoudig op sigself nie genoegsaam is vir die behartiging van die verantwoordelikhede wat siekesorg meebring nie. Om dit, soos Jonsen (1990:40-43), in terme van die suggestiekrag van die aangehaalde gelykenis te verduidelik: wat sou gebeur indien die Samaritaan onderweg na die herberg ook nog ander slagoffers teëkom? Sal hy op sy donkie plek hê vir almal? Sal daar in die herberg genoeg plek wees vir almal? Sal almal ewe goed behandel kan word? Wat is die implikasies daarvan dat die Samaritaan nie self die behandeling kan behartig nie, maar sy slagoffer(-s) in die hande van die herbergier moet laat en finansieel vir hul versorging voorsiening moet maak?

Die Samaritaan kan inderdaad funksioneer as 'n simbool van die moderne dokter. Hy beskik oor die deugde van kompetensie en medelye, maar hy kry daagliks te doen met meer siek mense as wat hy kan hanteer. Daarom word hy toenemend gedwing om nie slegs Samaritaan te wees nie, maar ook die hekwagter van die herberg (Jonsen, 1990:40). Die hekwagter-beeld gee iets weer van die probleem van die regverdige toewysing van skaars bronne wat so sentraal staan in die probleembewussyn van etici, dokters en almal wat teenswoordig met gesondheidsorg te make het. Daar is gewoon net te veel rower-slagoffers of siekes vir die ruimte en bronne van die herberg.

Hierdie probleem kry natuurlik nog 'n verdere dimensie as ons enersyds wil vashou aan die Samaritaan-motief wat erns maak met alle mense se aanspraak op goeie sorg, maar wat andersyds gekonfronteer word met die geweldige diskrepansie in bronne tussen samelewings. Jonsen, wie se werk tot nou toe dikwels ter sprake was, maak immers sy opmerkings teen die agtergrond van sy eie ervaring as etikus in 'n uitstekend toegeruste Amerikaanse hospitaal waar die dienste wat gelewer word, net die beste is, en waar die meerderheid pasiënte genoegsame finansiële ondersteuning het om te betaal. Selfs dáár is hierdie probleem akuut. Sedert die aanvang van die tagtigerjare is ook die Amerikaners toenemend opgesaal met die probleem, nie slegs wie nou toegang tot 'n enkele behandeling moet kry nie, maar hoe mense wat dit hoegenaamd nie kan bekostig nie, uherhaupt toegang tot enige vorm van gesondheidsorg kan kry. Die getal mense wat geen vorm van mediese versekering in die VSA het nie, is aan die begin van die tagtigerjare op 35 miljoen geskat. Daarby het die instelling van managed care sedert die begin van die negentigerjare die aandag gefokus op die skynbaar onbeheerbare eskalering van mediese koste in die Amerikaanse sisteem (vgl. vir 'n oorsig hiervan Morreim, 1995:1-41). Dit word, volgens 'n onlangse artikel in Time, bereken dat indien managed care nie in die VSA ingestel is nie, mediese onkoste heeltemal handuit sou geruk het. "In the late 1970s and early 
' 80 s, medical costs were rising at a rate that straight mathematical projection indicated would eventually consume the entire gross national product" (Church, 1997a:36). Hierteenoor wys die verdedigers van managed care daarop dat die stelsel in die VSA, met al sy erkende gebreke (bv. die gevaar dat dit insentiewe aan dokters bied om te min te behandel) 'n amper ongelooflike vermindering van mediese koste meegebring het. In 1996 het mediese koste in die VSA byvoorbeeld met slegs $2.5 \%$ gestyg, teenoor die $3.3 \%$ styging in verbruikerspryse (Church, 1997a:36).

Wat dan nou nog van die situasie in die Derde Wêreld, met name Suid-Afrika? Die dilemma van die hekwagter kry ontstellende inhoud as ons ag slaan op die beelde wat amper daagliks ons televisieskerms in hierdie land vul: eindeloos lang rye voor die wagkamers van buitepasiënte-afdelings, ernstige siek pasiënte in beddens sonder skoon (of enige) linne in die gange van Baragwanath- en/of Garang-Kuwa-hospitale, haglike, onhigiëniese toestande in "hospitale" in die Oos-Kaap (veral die ou Transkei). Die dilemma word benadruk as 'n mens let op syfers wat aandui dat epidemies soos vigs, tuberkulose en malaria amper buite beheer is, groot bedrae geld van tersiêre sorg weggeneem word en toegeken word aan primêresorgklinieke, terwyl alles daarop dui dat laasgenoemde klinieke nie van die grond af kom nie en dat die stroom pasiënte wat by groot, tersiêre hospitale soos Tygerberg en Groote Schuur aanmeld, steeds groter word, ensovoorts. Volgens die jongste syfers tot my beskikking (vgl. Van Niekerk, 1993:8) is slegs $23.6 \%$ van alle Suid-Afrikaners lede van 'n mediese hulpfonds. Die syfer verhul egter die rasgekenmerkte kompleksiteit van die werklike situasie. Dit blyk naamlik dat $81.3 \%$ van alle wit Suid-Afrikaners wel lede is van sulke fondse, teenoor slegs $3.6 \%$ van swartes. Hoewel jonger syfers hieroor nie tans beskikbaar is nie, is die aanduidings dat die relatiewe posisie van swart en wit in Suid-Afrika tans nog slegter daar uitsien as wat hierdie syfers reflekteer.

Wie moet gehelp word? Wie moet eerste gehelp word? Wie moet (of kan!) betaal, en hoeveel? Hoe moet betaal word? Die feit is dat medici se kompetensie geweldig uitgebrei het. Maar daardie kompetensie verorber soos 'n bloedsuier die (veral) finansiële bronne van die privaat- en openbare sektore van gesondheidvoorsiening.

Daarby is talle van die beginsels waarop soms in teorie staatgemaak word vir beslissings in hierdie verband hopeloos ontoereikend. As antwoord op die vraag wie eerste gehelp moet word, word dikwels teruggeval op die beginsel van triage (Frans vir kies en keur). Die woord is afkomstig van die Napoleontiese oorloë toe Baron Larrey moes kies watter soldate eerste gehelp moes word op die slagveld. Sy kriterium was eenvoudig: diegene wat die beste kans het op 'n vinnige herstel sodat hulle weer kon gaan oorlog maak! Die beginsel is nutteloos in die hedendaagse kliniese praktyk; dit erken bloot die feit dat 'n moeilike 
Anton A. van Niekerk

besluit geneem moet word. In praktyk vind ons dat in hedendaagse afdelings vir noodgevalle presies die teenoorgestelde beginsel as tydens 'n oorlog geld!

Of daar ooit 'n werklik bevredigende beginsel vir die rantsoenering van gesondheidsdienste gevind sal word, is myns insiens te betwyfel. (Vir 'n deurtastende bespreking van die etiek van rantsoenering in terme van makro- en mikro-allokasie, vgl. Beauchamp \& Childress, 1989:283-306.) Ek beweer dat dit te betwyfel is of ' $n$ bevredigende beginsel vir die rantsoenering van gesondheidsdienste gevind sal word omdat daar noodwendig geen "neutral, impersonal, tradition-independent standards of rational judgement" bestaan nie (MacIntyre, 1988:395). Ek sê dit eerder omdat dit skyn asof Jonsen korrek is as hy beweer dat "the work of medicine is incompatible with any strong theory of justice" (Jonsen, 1990:45). Ook Paul Ramsey, wanneer hy die "dramatiese" vraag aanraak van "how we must choose how to choose who shall live or die" voer aan dat "[t]he larger questions of medical and social priorities are almost, if not altogether, incorrigible to moral reasoning" (Ramsey, 1970:240).

In verskillende tradisies van gesondheidsorg - Hippokraties, Samaritaans, Caboteaans - kry ons verskillende voorstelle insake rantsoeneringsbeginsels wat ons sou kon toepas. Die Samaritaan sou immers dwaas wees om meer slagoffers op sy donkie te laai as wat dié kan dra of wat in die herberg versorg kan word. Caboteaanse etiek vereis insgelyks dat slegs diegene behandel word wat met onkreukbare professionele kompetensie behandel kan word. In die Caboteaanse tradisie was daar ook van oudsher af ' $n$ gesonde skepsis teenoor over-treatment, veral waar laasgenoemde geskied onder die voorwendsel van "doen alles wat moontlik is". Ook die Hippokratiese tradisie verskaf 'n rantsoeneringsbeginsel: slegs "proporsionele" behandeling is verpligtend. Daarmee word bedoel: behandeling wat vir die pasiënt meer van 'n bate as 'n las beskou kan word.

Ten aanhoor van hierdie riglyne kan ' $\mathrm{n}$ mens nie anders nie as om gelaat te word met die indruk van hoe dun die ys is waarop 'n mens beweeg. Nóg die Hippokratiese, nóg die Caboteaanse etiek bied deurslaggewende riglyne vir optrede ten opsigte van almal wat wag om behandel te word. Die essensiële morele probleem van die dokter as hekwagter het te make met die graad van sekerheid wat vereis word vir die oordeel dat 'n bepaalde moontlike prosedure nodig of suksesvol sal wees. Ek het saam met Jonsen (1990:57) dié aanvoeling:

The old tutiorist rule requires the physician to apply a procedure that offers any chance of saving life. A more relaxed view would allow the selection of a level of probability or a reasonable chance. It would remove from the moral vocabulary of medicine the phrase 'Do everything' and substitute 'Do as much as is reasonable'. 
Ou wyn in mrwe sakke: werk die ou etiek vir die mowe geneeskunde?

Dit kan inderdaad aangetoon word dat die beginsels van drie tradisies van mediese sorg (Samaritaans, Hippokrateaans en Caboteaans) laasgenoemde aanspraak gesamentlik ondersteun. (Vir so 'n argument, vgl. Jonsen, 1990:57-58.) Die motief vir optrede in hierdie geval is nie primêr koste nie, maar geregtigheid in die Aristoteliaanse sin: "a state of character which makes people disposed to do what is just, makes them act justly and wish for what is just" (Nichomachean Ethics 5.1.1129a; kyk Aristoteles, 1976). Dit openbaar 'n ingesteldheid wat die kompetente mediese praktisyn daartoe laat neig om elke pasiënt te behandel met so 'n volledig moontlike reeks bronne as wat versoenbaar is met die behoefte van ander onbekende en tot nog toe ongesiene pasiënte om sorg te ontvang wanneer hul beurt kom

Ek het geen illusies oor die reeks besware wat ingebring sou kon word teen wat ek pas gestel het nie. Dis egter genoeg om in hierdie stadium te volstaan met die aanspraak dat ek pleit vir 'n vermoë om nie net hierdie pasiënt voor jou raak te sien nie, maar al die potensiële pasiënte wat ook nog gaan kom. Dit noop die dokter om die idee van "alles moontlik" wat vir die pasiënt gedoen sou kon word, prys te gee ten gunste van "alles wat waarskynlik voordelig" sal wees.

\section{Die grense van dokters se regte}

'n Derde en laaste 6 tema waarop ek wil wys ten opsigte van die radikaal nuwe en veranderde omstandighede waarin etiese besinning oor biomediese praktyke deesdae moet plaasvind, is die dramatiese verskuiwings wat oor die afgelope aantal dekades in beskouinge oor die regte van dokters en pasiënte plaasgevind het. In die jongste literatuur oor mediese etiek kom hierdie kwessie gewoonlik ter sprake onder die hoof "paternalisme in die geneesheer-pasiënt-verhouding"7, waarby dan inbegrepe is besprekings van die kontroversiële kwessie van pasiënteregte (insluitend die reg om behandeling vir jouself en/of afhanklike kinders of onbevoegde volwasse familie te weier), kwessies rondom vertroulik-

6 'n Vierde tema wat in hierdie verband ook emstige aandag verg, is dic kwessic van tegnologie en die wyse waarop tegnologiese vernuwing medies-cticse besinning beïnvloed. Ek laat dit egter vir die comblik oorstaan, deels omdat dit so vervleg is met die ander temas wat ek bespreek, maar ook omdat ek elders aan die kwessics meer aandag gegec het (vgl. Van Nickerk \& Van Zyl, 1995a en 1995b)

7 Vgl twee prominente voorbeclde: Ackerman en Strong (1989:3-44), asook Beauchamp en Childress (1989:307-365). Dit is beduidend hoc prominent hierdie kwessie is - ook in laasgenoemde werk, wat toenemend beskou word as dic standaardhandbock vir studic in die mediese etick. 
Anton A. van Niekerk

heid, waarheid en privaatheid, ingeligte toestemming (informed consent) ${ }^{8}$, ensovoorts

Die problematiek wat hier aan die orde is, spruit voort uit gewone mense se groeiende aandrang daarop om betrokke te wees by besluitneming oor sake in verband met hul gesondheid en behandeling; vandaar die groeiende aandrang op informed consent, maar ook die probleme wat die aandrang by medici en regsgeleerdes wek. Wat verder hienuit voortvloei, is die eise wat die intensiewe litigasiekultuur van veral die VSA aan die praktyk van geneeskunde stel. Dis natuurlik 'n tendens wat toenemend uitkring na ander lande, veral diegene met handveste van menseregte. Dit is redelik maklik om te voorspel dat ' $n$ groeiende bewussyn van die probleme wat in die vorige paragraaf vermeld is, sowel as die daaruit voortvloeiende litigasiekultuur, waarskynlik spoedig na Suid-Afrika sal oorspoel namate die idee van ons Handves gevestig raak en die Konstitusionele Hof behoorlik begin funksioneer. Daar is waarskynlik nog veels te veel selfvoldaanheid onder beoefenaars van die mediese beroep in Suid-Afrika oor die gesag van hul oordeel en die onaantasbaarheid van hul besluite. Terselfdertyd sal dit ons loon om te waak teen die heksejag wat die Amerikaanse litigasiekultuur soms veroorsaak. Daar is in hierdie verband belangrike lesse wat ons betyds by die buiteland kan en behoort te leer.

Wat is in wese hier aan die gebeur? Robert Berenson het 'n aantal jare gelede die volgende in 'n artikel in die New York Times gesê:

Practicing (sic) medicine today means being caught in the middle. Insurers, government agencies, hospitals, one's own patients, put the squeeze on the doctor as they all press for their own interests or rights. Most doctors accept the inevitable conflicts between cost and quality, patient wishes and clinical judgement, professional autonomy and consumer protection Nevertheless, physicians feel increasingly beleaguered. Their recommendations and decisons are being questioned, constrained and overruled (Berenson, 1989, soos ook aangehaal deur Jonsen, 1990:80).

As 'n mens die omvang van die litigasiekultuur rondom wanpraktyke en regteskendings in geneeskunde in veral die VSA, maar ook talle ander Westerse lande in ag neem, dan is dit geen wonder nie dat dokters soos dr. Berenson voel asof hulle beleër en bedreig word. Wat egter in werklikheid in hierdie lande aan't

8 Tydens 'n onlangse ervaring as navorser en gasprofessor aan 'n Amerikaansc Mediesc Skool het ek opnuut onder die indruk daarvan gekom dat dit geen oordrywing is om te beweer dat ingeligte tocstemming dic sentrale waarde is in terme waarvan mediese etick tans in die VSA bedryf word nic. Vir 'n deurtastende bespreking van dic eticse en regskwessies rondom ingeligte toestemming, kyk die artikels van (Kate) Brown, Jameton, Beauchamp, Faden, Levine, Arnold, Lidz, Katz, (Alan P.) Brown en Brennan in Reich el al. (eds ), 1995:1221-1270 
gebeur is, en kort voor lank ook in SA sal gebeur, is dat die etos van geneeskunde wesenlik besig is om te verander. Die begrip "etos" moet onderskei word van die begrip "etiek". Laasgenoemde verwys na 'n wysgerige dissipline waarin besin word oor die reels, beginsels en deugde in terme waarvan die moraliteit (of behorenseis) van handelinge bepaal word - kortom, dit verwys na die filosofiese studie van die morele lewe. "Etos", daarenteen, verwys na die eiendomlike gees en oortuigings van ' $n$ gemeenskap of samelewing. Hierdie oortuigings mag die samelewing se etiek insluit, maar is nie tot laasgenoemde beperk nie. Etiek kan nie sonder etos verstaan word nie. Alle reels, beginsels en deugde kan wel in proposisies en/of definisies geformuleer word, maar het nogtans 'n eiesoortige toonaard en kleur in verskillende gemeenskappe.

Ter illustrasie kan ons wys op die verskil tussen die etos van "edelheid" (nobility) wat kenmerkend was van geneeskunde aan die begin van hierdie eeu in Brittanje, en die situasie wat ons vandag in 'n samelewing soos die VSA aantref (Jonsen, 1990:61-79). Dokters het naamlik in die Brittanje van die 18de eeu 'n taamlike slegte openbare reputasie gehad, maar het in die loop van die 19 de eeu langsamerhand daarin geslaag om nuwe en verhoogde status te verkry - 'n ontwikkeling wat natuurlik saamloop met die sukses van die ontwikkeling van die empiriese wetenskappe in die $19 \mathrm{de}$ eeu, en die toepassings vandaar in die geneeskundige wêreld. Florence Nightingale se onbaatsugtigheid gedurende die Krim-oorlog het insgelyks veel bygedra tot die ontwikkeling van 'n nuwe etos. (Vgl. in hierdie verband Woodham-Smith, 1964, asook Nightingale se eie werk Nightingale, 1969.) Toenemend is oor geneeshere gedink as mense wat ' $n$ "edele tak" verrig, en wat daarom ook as edeles gesien en behandel moet word. In 'n klassegeoriënteerde samelewing soos Engeland het dit kort voor lank ook gepaard gegaan met formele inwyding in die belonings van klassemeerderwaardigheid. Jonsen (1990:62-69) wys in dié verband veral op die hoogtepunt van hierdie kultuur, naamlik die toekenning van 'n baronskap aan Sir William Osler, regius professor in Geneeskunde aan die Universiteit van Oxford tydens die kroning van George $\mathrm{V}$ in 1910.

Hierdie erkenning vanuit die samelewing is natuurlik spoedig vasgelê in dokters se selfbeeld. Die edelheidstatus was een van die aanleidende oorsake vir die ongekende gesag wat met verloop van tyd toegeken is aan dokters en hul oordele oor wat 'n pasiënt makeer en hoe hy/sy daarvoor behandel moet word. Hierdie gesag is natuurlik beduidend versterk deur die wyse waarop die klassestratifikasie van 'n samelewing soos Brittanje op geneesheer-pasiënt-verhoudings gesuperponeer is. Die blanke gemeenskap van Suid-Afrika is natuurlik, hoe graag dit in baie kringe ook al ontken word, radikaal deur die Engelse beïnvloed. Dit het alhier eweneens daartoe aanleiding gegee dat, in die loop van die 19de en tot laat in die 20 ste eeu, twee beroepe met oordadige gesag en status beklee is: dié van dokter en predikant. Die eerste sien om na 'n mens se welsyn duskant die 
graf, en die tweede na jou welsyn anderkant die graf. In SA was die ongelykheid tussen dokter en pasiënt natuurlik nie primêr veroorsaak deur klasse-ongelykheid nie, maar deur kennisongelykheid. Die dokter en die dominee was eenvoudig die geleerdste mense - baie meer as selfs die mees gerespekteerde van ander sterwelinge in die gemeenskap. Terwyl ek meen dat daar met sekerheid gesê kan word dat die amp van predikant in die SA van vandag - ook in die Afrikanergemeenskap - grootliks ge-"ontmitologiseer" is en gestroop is van buitengewone status, is dit nog nie waar van die geneesheer nie. In 'n groot mate bly laasgenoemde nog steeds die persoon wie se woord wet is vir gewone sterwelinge. Die pretensie is dat sy oordeel berus op hoogs geprivigileerde kennis waarvoor duur betaal is - kennis wat slegs na die strengste keuring bekom kon word, en wat so waardevol is dat dit hom/haar aanspraak laat maak op die hoogste lewenstandaard wat die samelewing kan bied.

Die een samelewing waarin die ontmitologisering van die geneesheer egter grootliks voltrek is, is die VSA. Myns insiens is drie faktore veral daarvoor verantwoordelik.

- Die eerste is die afwesigheid van 'n klassestratifikasie van die samelewing op die Britse patroon. Dit het dit vir dokters moeiliker gemaak om (ook letterlik!) "edeles" te word.

- Die tweede is die aansprake, prototipes en bygevolg helde van die kru materialistiese kultuur van die Amerikaners. Diegene wat daar geïdealiseer word, is nie die edele geneeshere nie, maar die ryk entrepreneurs, nie die erfgename van ou geld nie, maar diegene wat arm begin het en die rykstes geword het - die vervullers van die American dream.

- Die derde faktor is die impak van die Handves van Menseregte in die Amerikaanse grondwet - 'n kultuurskeppende dokument wat mense as gelykes voor God, die reg en mekaar stel en wat die identifisering en beskerming van persoonlike regte 'n essensiěle tydverdryf van die nasionale kultuur maak. Dit sou daarom net 'n kwessie van tyd wees voor die moontlike inbreuk op persoonlike regte deur sekere geneeskundige praktyke 'n populêre item op die nasionale agenda sou word.

Die kwessie van menseregte ${ }^{9}$ blyk dus van deurslaggewende invloed te wees op verskuiwings in opvattings oor die status en gesag van geneeshere, en bygevolg vir die verstaan en inkleding van die verhouding tussen dokter en pasiënt in ons tyd. Pasiënte dring toenemend aan op hul reg tot privaatheid, tot volle inligting en

Vir 'n uitstekende bespreking van die menseregteproblecm is. gesondheidsorg, vgl. Van Zyl (1994). 
Ou wyn in muwe sakke: werk die ou etiek vir die nuwe geneeskunde?

medebesluitneming oor hul behandeling, tot die beste moontlike behandeling en tot beskerming teen wanpraktyke. Dit is daarom ook nie vreemd nie dat dokters terugkap met 'n beroep op ook húlle regte. Dokters begin toenemend aanvoer dat regulasies, institusionele beperkings, wanpraktykdreigemente en druk van pasiënte inbreuk maak op hul reg om geneeskunde te beoefen "in ooreenstemming met my vermoë en oordeel", soos die Eed van Hippokrates dit stel. Dikwels voer hulle aan dat die beperkinge van 'n sisteem van managed care hul reg om die beste vir hul pasiënte te doen, beperk. (Insake die stelsel van managed care en die jongste probleme met hierdie stelsel, soos dit tans in die VSA funksioneer, kyk Church, 1997a en 1997b.) Hulle meen dat hul reg op 'n sekere lewenstandaard in die gedrang kom deur voorstelle wat die effek kan hê dat hul inkomste beheer word, of dat hul keuses oor 'n spesialisasierigting en die plek waar hulle kan praktiseer, beheer of voorgeskryf word. In Suid-Afrika is daar byvoorbeeld groeiende besorgdheid oor die brain drain van medici, en gaan al hoe meer stemme op dat dokters, nadat hulle afgestudeer het, verplig behoort te word tot 'n periode van "gemeenskapsdiens", veral in plattelandse gebiede. Die vaag is natuurlik wat die implikasies hiervan is in 'n samelewing met 'n Menseregtehandves, en hoekom slegs medici in hierdie verband uitgesonder word.

Ek meen dat 'n mens veel simpatie kan hê met dokters wat meen dat sommige van hul fundamentele regte bedreig word. Ek meen egter dat die kernverskuiwing wat in hierdie verband besig is om plaas te vind, die feit is dat dokters voortaan nie meer toegelaat gaan word om eensydig te besluit oor die terme waarin die dokter-pasiënt-verhouding gestruktureer word nie. Hierdie toedrag van sake vта om enkele verduidelikende opmerkings

In sy bespreking van hierdie kwessies, wys Jonsen (1990:84-89) daarop dat ons hedendaagse konsepsie van regte in hoofsaak afgelei is van die insigte van die beroemde 17de-eeuse filosoof, John Locke, wat self 'n geneesheer en medewerker van die ewe beroemde "Engelse Hippokrates", Thomas Sydenham, was. Hul onderlinge interaksie en Locke se interpretasie van Sydenham se prestasies het geen geringe invloed uitgeoefen op die wyse waarop dokters se regte tot in ons tyd verstaan is nie. Sydenham het naamlik daarvoor beroemdheid verwerf dat hy, anders as Hippokrates, nie slegs die geskiedenis van siek mense beskryf het nie, maar die geskiedenis van siektes. Vir Hippokrates was daar net siekte, en laasgenoemde was in elke manifestasie verweef met die lewensgeskiedenis van die persoon wat daaraan ly. Deur middel van sy empiriese metodes kon Sydenham egter die grondslag lê vir die wetenskap van die patologie: die studie van siektes. Daardeur kon hy aantoon dat 'n siekte 'n naam het, deur bepaalde dinge veroorsaak is, eiesoortige (en soms unieke) kenmerke/ simptome het, en op eiesoortige behandelingsvorme reageer. Dit was 'n geweldige deurbraak, want daardeur het geneeshere mag verkry oor siektes. Dit 
was primêr in terme van hierdie ongekende mag wat geneeshere oor siekte begin verwerf het dat dokter-pasiënt-verhoudings in die volgende paar eeue grootliks gestruktureer is. Die primêre reg van die geneesheer was voortaan sy vryheid om sy verhouding met 'n pasiënt op so 'n wyse te struktureer dat dit die voordele sou oplewer wat hy kon aanbied deur die toepassing van sy wetenskaplike vaardighede.

Ek wys net baie kortliks op twee verdere aspekte

- Die eerste is dat dokters geneig was om die kennis waaroor hulle beskik, te verstaan binne die konteks van die Lockeaans geinspireerde regtekultuur, en wel na analogie van eiendomsregte (Jonsen, 1990:90-93). Die geneesheer beskik oor kennis wat hy beskou as eiendom. As ons daarby aanvaar dat die dokter benevolent is, dit wil sê dat hy daarin geïnteresseerd is om sy kennis en vaardighede tot voordeel van die pasiënt aan te wend, dan volg dit dat hy mag het oor die aard van die verhouding wat hy met die pasiënt het. Sy praktyk is sy eiendom; dit word tot stand gebring deur opleiding, werk en ervaring. Diegene wat die kennis van die dokter benodig, tree in 'n vertrouensverhouding met hom waarin hulle hulself toevertrou aan sy goedgunstigheid en kennis. Die dokter kan hierdie kontrak, waarin van hom verwag word om voordele aan sy pasiënt te laat toekom, slegs vervul as hy, en hy alleen, die voorwaardes daarvoor stel en toesig hou oor die pasiënt se instemming daarmee ("kom sien my weer oor drie dae"!). Die dienste wat hy lewer, is diskreet en kan geprys en gekoop word. Indien die pasiënt nie hou by wat van hom verwag word nie, of as die natuur nie wil reageer soos dit veronderstel is om te reageer nie, word die dokter vrygestel van verantwoordelikheid, sonder dat dit beteken dat die pasiënt se verantwoordelikheid om steeds te betaal, opgehef word. Hieruit blyk dus: die terme van die verhouding tussen dokter en pasiënt word eensydig bepaal deur die dokter op grond van sy superieure kennis en die aanname dat hy werk tot voordeel van die pasiënt. In so 'n konteks is daar uiteraard weinig sprake van die regte van pasiënte; die dokter se woord is wet en daar bestaan weinig gronde om die dokter op enige punt teë te gaan.

- 'n Verdere konsekwensie van hierdie beskouing (die tweede aspek waarop ek wil wys), ook as uitvloeisel van Sydenham se bydrae, is dat dokters meen dat hulle 'n "reg teen die siekte" het wat dikwels sterker is as die pasiënt se beskikkingsreg oor sy eie liggaam. Die siekte mag nou in die liggaam van die pasiënt teenwoordig wees, maar die siekte is primêr daar vir die dokter om oor te beskik, dit wil sê om te verwoes. "The belligerent metaphors of medicine, in which physicians 'fight disease with aggressive therapies' suggest that forays into the territory occupied by the enemy may occasionally overrun the 
Ou wyn in mowe sakke: werk die on etiek vir die mowe geneeskunde?

rights of the inhabitants" (Jonsen, 1990:94).10 Dokters beleef dit daarom baie sleg wanneer hulle deur die pasiënt, of deur ander bemoeisieke beheerliggame, verbied word om by die siekte uit te kom en dit te likwideer.11

Die relatief onlangse aanvaarding van die idee van ingeligte toestemming (informed consent) in die etiese kodes van dokter-pasiënt-verhoudings word, al bied dit 'n welkome afwyking van vroeëre patemalisme, deur baie dokters steeds as onaanvaarbaar beleef. Hulle meen dat dit hul verbintenis tot die pasiënt se welsyn onnodig uitdaag. Die gedagte dat pasiënte die reg kan hê om behandeling te weier, is vir sommige dokters gewoon 'n "outrage"12. "The many invasions felt by physicians come from patients' claims over their bodies and minds which in the Lockean metaphor, belong to the physician, at least when those bodies and minds are diseased" (Jonsen, 1990:94)

Dis is hierdie ou etos van die geneeskunde wat in ons nuwe (post-) moderne situasie radikaal uitgedaag word, en wat insgelyks 'n radikaal nuwe uitdaging aan ons opvattings van "reg" en "moreel" stel. Soos wat tegnologiese vernuwing ons sensitief moet maak vir die grense van medici se bevoegdheid, en soos beperkte bronne ons noodsaak om keuses te maak wat grense stel aan ons medelye, so stel (post-) moderne mense se aandrang op vryheid, outonomie en mede-

10 Vergelyk in hierdie verband ook Susan Sontag se bespreking van die aggressicwe, militêre metafore waarmee siekte en behandeling (veral in die geval van kanker) in die twintigste ceu omskryf word Hierdie "aggressiewe" metafore staan tcenoor die "romantiese" metafore waarmee tuberkulose, wat die oorheersende siekte van die negentiende ecu was, beskryf is (bv. "consumption"). Sontag is 'n skrywer wat self van kanker genees is (vgl. Sontag, 1977)

11 Dic klassieke geval is Jehovagetuies se weicring om bloed te ontvang, maar daar is 'n recks ander standaardgevalle hiervan, byvoorbecld die weiering om kankerbehandeling te ondergaan, ensovoorts. Vergelyk ook Patterson (1987) se bespreking van die wyse waarop die bchandeling van kanker in die VSA in 'n establıshment-kultuur in die loop van die twintigste eeu ontwikkel het - 'n kultuur waarin geneeshere se "reg" om die siekte op 'n sekere, konvensionele manier te behandel, orheersend erken en verdedig is, ten spyte van "kontra-kultuur" lobbies (bv. diegene wat kanker tocnemend begin toeskryf het aan dieet- en omgewingsprobleme) se uitdagings aan hierdic kultuur.

12 Hierdie situasie word natuurlik ook oneindig gekompliseer in gevalle waar ouers namens kinders sulke besluite (wil) neem Ek het persoonlik ervaring van situasies waar Jehova-getuies 'n blocdoortapping weler vir ' $n$ kind wat aan leukemie ly. In Suid-Afrikaanse wetgewing bestaan daar prosedures vir medici om sodanige weiering te ignoreer: die supcrintendent van 'n hospitaal mag byvoorbocld plaasvervangende toestemming vir so 'n oortapping verlecn - myns insiens heeltemal tereg. Terwyl ek gee.ı problecm daarmee het dat 'n mens behandeling vir jouself as volwassene (18 jaar en ouer) kan weier nie, het 'n mens nie die reg om sodanige besluite vir en namens ander - ook jou minderjarige kunders - te neem nie. Trouens, jy het die morele plig om alles moontlik te doen om toe te sien dat alles wat vir so 'n pasient voordelig mag wees (weer cens: nic "alles moontlik" nie!) gedoen sal word. 
Anton A. van Niekerk

verantwoordelikheid vir hul liggaam en situasie grense aan die regte van dokters, soos verstaan in die tradisie van Locke en Sydenham.

Vandag word die volgende vrae toenemend in etiese besinning gestel: moet dokters toegelaat word om 'n prenatale diagnose te maak wat kan lei tot die abortering van die fetus bloot omdat laasgenoemde manlik of vroulik is? Behoort genetiese tipering (genetic screening), wat individue mag mislei, verwar of sosiaal kompromitteer, as 'n tegniek tot beskikking van dokters gestel word? Behoort erg premature babas gered te word indien hul kanse op 'n normale lewe uiters skraal is? Moet 'n geaborteerde fetus wat lewend gebore word, geresussiteer word? Moet dokters toegelaat word om kunsmatig onderhoue lewe te termineer? Regverdig al die kostes van moderne mediese tegnologie die vrugte daarvan? Dokters bepaal of en watter duur diagnostiese en terapeutiese tegnologie gebruik moet word: is dit billik teenoor die pasiënt, sy familie en die gemeenskap? Al hierdie vrae bevraagteken die geskiktheid en alleenmag van die dokter as besluitnemer. Daar is inderwaarheid talle kritici van die moderne geneeskunde wat beweer dat, gewapen met hul steeds uitkringende tegnologie, hedendaagse medici meer kwaad en ongelukkigheid skep as wat hulle genees. Bogenoemde vrae is 'n aanduiding van groeiende twyfel, nie soseer oor die bevoegdheid of vaardighede van moderne geneeshere nie, maar wel oor hul welwillendheid (Jonsen, 1990:99). Wat radikaal bevraagteken word, is of selfs die dokter met die beste bedoelings en die minimum selfbelang werklik in ' $n$ posisie is om oor "die beste belange van ander" te besluit. Die aandrang groei dat hul oordeel aangevul en soms selfs vervang moet word deur dié van ander mense.

Persoonlik is ek van oordeel dat hierdie uitdagings aan die welwillendheid van medici dikwels, veral in 'n samelewing soos die VSA, totaal oordryf word en weinig regverdigbare gronde het. Dit doen egter nie afbreuk daaraan dat die paradigma vir die verstaan van die terme waarvolgens dokter-pasiënt-verhoudinge gestruktureer word, dramaties verander het nie. Die moderne geneeskunde word gekonfronteer met die onontwykbare uitdaging om die toepaslike verhouding tussen die regte van mediese praktisyns, pasiënte en diegene wat vir dienste betaal (die regering en die burgery) te vind. Alleen so sal, ook op hierdie terrein, die ou (maar daarom juis goeie!) wyn van 'n verantwoorde etiek tereg kom in die nuwe sakke van nie alleen 'n nuwe geneeskunde nie, maar ook 'n nuwe geslag pasiënte: mense wat daarop aandring om hul onvervreembare beskikkingsmag oor hul eie liggame in vennootskap met geneeshere te verwerklik.

\section{Bibliografie}

ACKERMAN, T.F. \& STRONG, C. 1989. A casebook of medical ethics. New York Oxford University Press.

ARISTOTELES 1976. The Nichomachean ethics Harmondsworth : Penguin Books 
Ou wyn in mowe sakke: werk die ou etiek vir die mowe geneeskunde?

BAUMAN, Z. 1993 Postmodern ethics. Oxford : Blackwell.

BEAUCHAMP, T L \& CHILDRESS, J.F. 19893. Principles of biomedical ethics. New York : Oxford University Press

BERENSON, R. 1989. Meet doctor squeezed. New York Times, Jul. 21.

CHURCH, G.J. 1997a. Backlash against HMOs. Time. 32-36, April 14.

CHURCH, G.J. 1997b. Twin cities' friendly plans. Time 36-39, April 14

FOX, R. \& SWAZY, J. 1974. The courage to fail: a social view of organ transplants and dialysis. Chicago : University of Chicago Press.

HARRIS, J. 1985. The value of life. London : Routledge

JONAS, H. 1974. Philosophical essays: from ancient creed to technological man. Englewood Cliffs : Prentice Hall.

JONSEN, A.J. 1990. The new medicine and the old ethics. Cambridge, Ma. : Harvard University Press.

MACINTYRE, A. 1981. After virtue: a study in moral theory London : Duckworth.

MACINTYRE, A. 1988. Whose justice? Which rationality? London : Duckworth.

MORREIM, H. 1995. Balancing act: The new medical ethics of medicine's new economics. Washington DC : Georgetown University Press.

NIGHTINGALE, F. 1969. Notes on nursing: what it is and what it is not. New York : Dover Publications.

PATTERSON, J.T. 1987. The dread disease: Cancer and the modern American culture. Cambridge, Ma. : Harvard University Press.

RAMSEY, P. 1970. The patient as person. New Haven \& London : Yale University Press

REICH, W T. el al. (eds ) 1995. Encyclopedia of Bioethics. New York : Simon \& Schuster Macmillan.

SONTAG, S. 1977. Illness as metaphor. Harmondsworth : Penguin Books

VAN NIEKERK, A.A. 1993. Health care as human right. Stellenbosch : Eenheid vir BioEtiek.

VAN NIEKERK, A.A. \& VAN ZYL, L. 1995a. The ethics of surrogacy: women's reproductive labour. Journal of Medical Ethics, 21:345-349

VAN NIEKERK, A.A. \& VAN ZYL, LL 1995b Commercial surrogacy and the commodification of children: an ethical perspective. Medicine and Law, 14(3/4):163170.

VAN ZYL, L.L. 1994. Geregtigheid en gesondheidsorg. Universiteit van Stellenbosch Annale, 1994/2: 1-51.

VIRCHOW, R. 1879. Gesammelte Abhandlungen aus dem Gebiete der Offentlichen Medicin. Berlin : Herschwald.

WOODHAM-SMITH, C 1964. Florence Nightingale, 1820-1910. London : Fonatana Books. 